International Research Journal of Management, IT \& Social Sciences
Available online at https://sloap.org/journals/index.php/irjmis/
Vol. 8 No. 2 March 2021, pages: 141-147
ISSN: 2395-7492
https://doi.org/10.21744/irjmis.v8n2.1300

\title{
Effect of Image and Brand Trust on Loyalty of Cement Baturaja
} Consumers

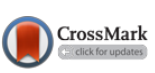

\author{
Basthony Santri ${ }^{a}$ \\ Zakaria Wahab $^{\text {b }}$ \\ Marlina Widiyanti ${ }^{c}$ \\ Muchsin Saggaff Shihab $^{\mathrm{d}}$
}

Article history:

Submitted: 09 November 2020

Revised: 18 December 2020

Accepted: 27 January 2021

\section{Keywords:}

brand image;

brand loyalty;

brand trust;

\begin{abstract}
This research was conducted to determine brand image and brand trust on consumer loyalty to Baturaja cement. All Baturaja cement consumers from September 2020 to October 2020 in the Lampung region were involved in this study. Likewise, a sample of 150 people obtained through a purposive sampling technique with several criteria of determination. Using a questionnaire distributed to all consumers, we can process the data using multiple linear regression analysis. Multiple linear analysis shows that brand image positively and significantly affects customer loyalty to the Baturaja cement brand. Likewise, brand trust has a positive and significant effect on consumer loyalty to the Baturaja cement brand. Meanwhile, the brand image is expected to update by making the product tagline more attractive, both from the color type, the tagline size that can be easier to remember and attract consumers. Brand trust is expected that the company can improve product quality and carry out more attractive promotions, with the status of a limited company Semen Baturaja does not guarantee that consumers will prefer Baturaja cement products.
\end{abstract}

International research journal of management, IT and social sciences (C) 2021. This is an open access article under the CC BY-NC-ND license (https://creativecommons.org/licenses/by-nc-nd/4.0/).

Corresponding author:

Basthony Santri,

Master of Management, Sriwijaya University, Indonesia.

Email address: basthony99@gmail.com

Master of Management, Sriwijaya University, Indonesia

Lecturer of Magister management Economic Faculty, Sriwijaya University, Palembang Indonesia

Lecturer of Magister management Economic Faculty, Sriwijaya University, Palembang Indonesia

Lecturer University Bakrie, Jakarta, Indonesia 


\section{Introduction}

The concrete business is one of the mainstays of financial improvement in Indonesia. Its part as one of the primary segments in the framework and building improvement makes concrete one of the foundation of the nation's advancement. Interest in concrete in Indonesia has expanded fundamentally as of late (Sidjabat et al., 2019; Setyawan et al., 2017; Ahmed et al., 2002; Agustia et al., 2020). Because of measurable information from the Indonesian Cement Association (ASI) in 2019, the development of concrete utilization in Indonesia shows a positive upward pattern, the normal development in 2018 arrived at 4.8\% in critical development from 2011 to 2019 (Novalius, 2019).

Table 1

Cement sales growth in Indonesia

\begin{tabular}{lll}
\hline Year & $\begin{array}{l}\text { Cement Sales in Indonesia } \\
(\text { Million Ton) }\end{array}$ & Growth $(\%)$ \\
\hline 2014 & 60 & 3,3 \\
2015 & 61 & 1,8 \\
2016 & 62 & 1,0 \\
2017 & 66 & 7,6 \\
2018 & 70 & 4,8 \\
2019 & 70 & 0,5 \\
\hline
\end{tabular}

Table 1, it can be seen from 2014 to 2019 that cement sales in Indonesia have increased. In 2014, it showed that cement sales in Indonesia amounted to 60 million tons with a growth percentage of $3.3 \%$. Furthermore, in 2015, cement sales in Indonesia had increased by 61 million tons or with a growth percentage of $1.8 \%$. Likewise, in 2016 cement sales in Indonesia increased with a growth of $1 \%$ compared to the previous year. In 2017, cement sales in Indonesia showed an increase in growth of 7.6\%. In 2018, cement sales in Indonesia increased by $4.8 \%$ and in 2019 by $0.5 \%$.

Limited company Semen Baturaja Tbk is a company engaged in the cement industry and is headquartered in Palembang, South Sumatra, and 2013 was listed on the Indonesia Stock Exchange (IDX). The type of cement produced by limited company Semen Baturaja, Tbk is Portland OPC Type I, OPC Type II and OPC Type V cement according to SNI 2049: 2015 and Portland Composite Cement (PCC) according to SNI 7064: 2014. By owning three factories, namely the Baturaja factory, the Palembang factory, and the Panjang factory, it will facilitate and reach markets in Southern Sumatra, namely Jambi, Bangka Belitung, Lampung, Bengkulu, and Palembang.

According to Crick \& Crick (2020), expanding business rivalry and combined with the Covid 19 pandemic, limited company Semen Baturaja, Tbk, is growing its technique to seek benefits during the Covid 19 pandemic (Abuselidze \& Slobodianyk, 2019; Adalja et al., 2020; Akhtaruzzaman et al., 2020). As indicated by the President Director of limited company Semen Baturaja, Tbk, Jobi Triananda Hasjim said that there are five primary methodologies to improve organization execution, including streamlining appropriation and thickening pockets with the enhancement of different incomes, to collaborations with bunch BUMN. The state of the Covid 19 pandemic has brought about digitalization on all fronts, including showcasing so that organizations construct advanced arrangements by shaping white naming.

\section{Materials and Methods}

In this examination, the populace were all customers who bought Baturaja concrete in the time frame September 2020 to October 2020 in the Lampung district. Examining was finished by utilizing the nonprobability testing procedure, by being the specific purposive inspecting technique (Wahyuni, 2012; Berg, 2001). Non-probability inspecting with purposive testing strategy is an examining procedure that does not give equivalent freedoms or freedoms to every populace's component to be chosen as an example. The example in this investigation was buyers who bought Baturaja concrete with different concrete kinds in the Lampung area. The example taken in this examination has the accompanying standards:

a) Customers who purchase Baturaja cement in the Lampung area;

b) Customers aged 18 years and over;

c) Customers who have used Baturaja cement. 
3 Results and Discussions

Results of Multiple Linear Regression Analysis

Table 2

Multiple Linear Regression Analysis

\begin{tabular}{clcccc}
\hline \multicolumn{5}{c}{ Coefficients } \\
Model & & \multicolumn{2}{c}{$\begin{array}{c}\text { Unstandardized } \\
\text { Coefficients }\end{array}$} & $\begin{array}{c}\text { Standardized } \\
\text { Coefficients }\end{array}$ & \\
\hline 1 & & $\mathrm{~B}$ & Std. Error & Beta & Sig \\
\hline & Constant & .600 & .251 & & \\
& Brand Image & .174 & .059 & .175 & .003 \\
& Brand Trust & .668 & .059 & .669 & .000 \\
\hline
\end{tabular}

$$
\mathrm{Y}=0,600+0,174 \mathrm{X}_{1}+0,668 \mathrm{X}_{2}+\mathrm{e}
$$

a) The constant value indicates a positive value with a value of 0.600 . This shows that brand loyalty is considered that without the influence of brand image and brand trust, the brand loyalty variable's magnitude is 0.600 ;

b) The relapse coefficient estimation of the brand picture variable is 0.174 with an estimation of 2.971 states that brand picture positively affects brand unwaveringness. This shows that the higher the brand picture, the positive effect, specifically the higher the unwaveringness of the Baturaja concrete brand;

c) The brand trust variable's regression coefficient value is 0.668 with a value of 11.381 , which states that brand trust has a positive effect on brand loyalty. This shows that the higher the brand trust is given, the positive impact, namely the higher the loyalty of the Baturaja cement brand (Odin et al., 2001; Fournier \& Yao, 1997).

Results of Correlation Coefficient ( $r$ ) and Coefficient of Determination $\left(R^{2}\right)$

Table 3

Correlation Coefficient (r) and Coefficient of Determination $\left(\mathrm{R}^{2}\right)$ Model Summary ${ }^{b}$

\begin{tabular}{lcclc}
\hline Model & $\mathrm{R}$ & $\mathrm{R}$ Square & $\begin{array}{l}\text { Adjusted R } \\
\text { Square }\end{array}$ & $\begin{array}{l}\text { Std. Error of the } \\
\text { Estimate }\end{array}$ \\
\hline 1 & .756 & .572 & .566 & .655358 \\
\hline
\end{tabular}

In light of the yield model outline in Table 3, the aftereffects of the connection coefficient (r) test show that the impact of brand picture and brand trust factors on brand dependability is 0.756 or $75.6 \%$. The greatness of the $R$ square $\left(R^{2}\right)$ the number is 0.572 or $57.2 \%$; this figure is utilized to perceive what brand picture and brand trust mean for brand steadfastness of Baturaja concrete. This figure expects how the factors of the brand picture and brand trust to show what variables can influence the Baturaja concrete brand's unwavering ness, and together, it is 57.2\%. In comparison, the excess $42.8 \%$ is impacted by different factors, such as administration quality, item quality, and advancement.

Significance Parameter Individual Test (test $t)$

Table 4

Significance Parameter Individual Test (test t)

\begin{tabular}{clccrc}
\hline \multicolumn{7}{c}{ Coefficients } \\
\hline Model & Variable & $\mathrm{B}$ & $\mathrm{t}_{\text {table }}$ & $\mathrm{t}_{\text {count }}$ & Sig. \\
\hline \multirow{2}{*}{1} & Brand Image & .174 & 1.976 & 2.971 & .003 \\
& Brand Trust & .668 & 1.976 & 11.381 & .000 \\
\hline
\end{tabular}

Santri, B., Wahab, Z., Widiyanti, M., \& Shihab, M. S. (2021). Effect of image and brand trust on loyalty of cement baturaja consumers. International Research Journal of Management, IT and Social Sciences, 8(2), 141-147. https://doi.org/10.21744/irjmis.v8n2.1300 
Based on Table 4. the value of degree of freedom $(\mathrm{df})=\mathrm{n}-\mathrm{k}=150-3=147$ and 0.05 , the value for this research data is 1.976. The results of the analysis can be explained as follows:

a) The estimation of the brand picture variable (X1) is 2.971 , and the importance esteem is 0.003 , the value $>$ is $(2.971>1.976)$ or the worth (Sig.) $0.003<0.05$. This implies that brand picture significantly affects brand faithfulness of Baturaja concrete. This demonstrates that the brand picture variable's primary speculation has a positive and critical impact is adequate.

b) The value of the brand trust variable (X2) is 11,381 and the significance value is 0,000 , the value > is $(11,381>$ 1,976 ) or the value (Sig.) $0,000<0.05$. This means that brand trust has a significant effect on the brand loyalty of Baturaja cement. This proves that the second hypothesis on the variable brand trust has a positive and significant effect is acceptable.

The brand picture depicts the extraneous idea of an item or administration, remembering the path for which they attempt to meet clients' mental or social necessities (Kotler, 2009; Kotler, 1987). The picture of the brand is identified with mentalities as convictions and inclinations for a brand. Shoppers who have a positive picture of a brand will be better ready to make buys and even brand dedication from buyers without a stable and positive brand picture; it is exceptionally hard for organizations to pull in new clients and hold existing ones (Setiadi, 2003; Rusmiati et al., 2020; Cretu \& Brodie, 2007). Buyers who believe that they are sure will be continuously joined to shape reliability to specific brands, which is called brand unwaveringness (Rossiter \& Bellman, 2005; Morrison, 2018). Reliability happens when there is a positive reaction from the buy and utilization experience for an item. The brand picture has a positive and critical impact on brand dependability. The aftereffects of this investigation are by research results (Faradisa, 2019; Hartati, 2019; Putra \& Sulistyawati, 2019), found that brand picture has a positive and critical impact on brand dedication.

The consequences of this examination show that brand picture is related with a few markers, for example, brand character, brand character, brand affiliation, brand demeanor and conduct, brand advantages, and ability. The marker "Baturaja concrete slogan is not difficult to recall and perceive" shows the most reduced worth. It is expected that the slogan on Baturaja concrete is not a central point for purchasers in becoming acquainted with Baturaja concrete items. This shows that the slogan of concrete Nataraja items does not affect brand reliability. On the pointer, "Baturaja concrete items have a decent picture among the general population" shows the most noteworthy score. This shows that the general population all around perceives Baturaja's concrete items. A decent organization picture will think that it is simpler to give customers positive reactions towards the organization by consistently utilizing Baturja concrete items.

Brand trust is the eagerness to confide in a brand with all the dangers on account of the assumptions guaranteed by the brand in giving positive outcomes to shoppers (Lau \& Lee, 1999; Zehir et al., 2011; Laroche et al., 2012). On the off chance that buyers have faith in a brand, they will keep on purchasing the brand, use it, and even educate others concerning the brand's upsides dependent on purchaser experience in utilizing that brand (Andryusalfikri et al., 2019). Brand trust affects buyer dedication. If shoppers put stock in these brands, purchasers will not change to different brands. Brand trust has a positive and critical impact on brand unwaveringness. This outcome is following research results from (Marliawati \& Cahyaningdyah, 2020; Qurbani \& Pasaribu, 2019; Fatikhyaid et al., 2019), that found that brand trust has a positive and massive impact on brand reliability.

The outcomes demonstrated that brand trust is related to a few pointers, for example, brand trademark, organization trademark, and buyer brand trademark. On the pointer, limited company Semen Baturaja, Tbk is a state-possessed organization, demonstrating the most reduced worth. It is expected that buyers do not think about the organization that sells concrete items, even though limited company Semen Baturaja, Tbk, a state-possessed organization, is not a factor impacting purchasers' staying faithful to the brand because dependent on-field reviews, the organization's status a stateclaimed or privately-owned business is not a benchmark for shoppers to be faithful to the brand. Since buyers will be faithful to brands, dependent on the nature of the items the organization produces. The marker "I accept that Baturaja concrete items are of acceptable quality shows the most elevated worth. This shows that shoppers now feel that the nature of Baturaja concrete items is of acceptable quality. The nature of the concrete created gives buyers a feeling of fulfillment with an item, which will affect shopper reliability to the brand. This shows that buyers truly trust the nature of the concrete items created by limited company Semen Baturaja, Tbk by demonstrating the most elevated outcomes. 


\section{Conclusion}

1. The brand picture has a positive and massive impact on the brand faithfulness of Baturaja concrete.

2. Brand trust has a positive and massive impact on the brand faithfulness of Baturaja concrete

\section{Conflict of interest statement}

The authors declared that they have no competing interests.

Statement of authorship

The authors have a responsibility for the conception and design of the study. The authors have approved the final article.

\section{Acknowledgments}

The researchers expressed the highest appreciation to everyone who has been involved fully in writing this project entitled "THE INFLUENCE OF IMAGE AND BRAND TRUST ON CONSUMER LOYALTY OF SEMEN BATURAJA," Especially the coauthors who have provided full jobs in completion of this paper. Together with all seniors in the department and editing support from the college. We are as authors, have finished this work with our financial support.

Santri, B., Wahab, Z., Widiyanti, M., \& Shihab, M. S. (2021). Effect of image and brand trust on loyalty of cement baturaja consumers. International Research Journal of Management, IT and Social Sciences, 8(2), 141-147. https://doi.org/10.21744/irjmis.v8n2.1300 


\section{References}

Abuselidze, G., \& Slobodianyk, A. (2019, December). Pandeconomic crisis and its impact on small open economies: a case study of COVID-19. In Energy Management of Municipal Transportation Facilities and Transport (pp. 718728). Springer, Cham.

Adalja, A. A., Toner, E., \& Inglesby, T. V. (2020). Priorities for the US health community responding to COVID19. Jama, 323(14), 1343-1344.

Agustia, D., Muhammad, N. P. A., \& Permatasari, Y. (2020). Earnings management, business strategy, and bankruptcy risk: evidence from Indonesia. Heliyon, 6(2), e03317. https://doi.org/10.1016/j.heliyon.2020.e03317

Ahmed, P. K., Lim, K. K., \& Loh, A. Y. (2002). Learning through knowledge management. Routledge.

Akhtaruzzaman, M., Boubaker, S., \& Sensoy, A. (2020). Financial contagion during COVID-19 crisis. Finance Research Letters, 101604. https://doi.org/10.1016/j.frl.2020.101604

Andryusalfikri, Wahab., Z, \& Widiyanti, M. (2019). Effect of Trust, Quality of Products and Quality Services on Purchase Decisions on E-Commerce Shopee in Palembang City-PDF Free Download. International Journal of Management and Humanities (IJMH), 3(12), 1-6.

Berg, B. L. (2001). Qualitative research methods for the social sciences, Allyn and Bacon. Boston et al, $238-267$.

Cretu, A. E., \& Brodie, R. J. (2007). The influence of brand image and company reputation where manufacturers market to small firms: A customer value perspective. Industrial marketing management, 36(2), $230-240$. https://doi.org/10.1016/j.indmarman.2005.08.013

Crick, J. M., \& Crick, D. (2020). Coopetition and COVID-19: Collaborative business-to-business marketing strategies in a pandemic crisis. Industrial Marketing Management, 88, $206-213$. https://doi.org/10.1016/j.indmarman.2020.05.016

Faradisa, N. A. (2019). Pengaruh Komunikasi Merek, Citra Merek Dan Kepercayaan Merek Melalui Media Online Terhadap Loyalitas Merek Pada E-Commerce (Studi Kasus Pada Pengguna e-Commerce di FE UII).

Fatikhyaid, M., Rachma, N., \& Hufron, M. (2019). Pengaruh Brand Image, Brand Awareness dan Brand Trust Terhadap Brand Loyalty Pengguna Smartphone Merek Samsung (Studi Kasus Pada Mahasiswa Fakultas Ekonomi dan Bisnis Unisma). Jurnal Ilmiah Riset Manajemen, 8(10).

Fournier, S., \& Yao, J. L. (1997). Reviving brand loyalty: A reconceptualization within the framework of consumerbrand relationships. International Journal of research in Marketing, 14(5), 451-472. https://doi.org/10.1016/S0167-8116(97)00021-9

Hartati, D. R. (2019). Pengaruh Kualitas Produk, Brand Image Dan Brand Trust Terhadap Loyalitas Melalui Kepuasan Nasabah Sebagai Variabel Intervening (Studi Kasus Pada BPRS Dana Amanah Surakarta) (Doctoral dissertation, IAIN Salatiga).

Kotler, P. (1987). Manajemen Pemasaran: Analisis, Perencanaan, Dan Pengendalian. Erlangga.

Kotler, P. (2009). Marketing Management. Pearson Prentice Hall.

Laroche, M., Habibi, M. R., Richard, M. O., \& Sankaranarayanan, R. (2012). The effects of social media based brand communities on brand community markers, value creation practices, brand trust and brand loyalty. Computers in Human Behavior, 28(5), 1755-1767. https://doi.org/10.1016/j.chb.2012.04.016

Lau, G. T., \& Lee, S. H. (1999). Consumers' trust in a brand and the link to brand loyalty. Journal of Market-Focused Management, 4(4), 341-370.

Marliawati, A., \& Cahyaningdyah, D. (2020). Impacts the brand of experience and brand image on brand loyalty: Mediators brand of trust. Management Analysis Journal, 9(2), 140-151.

Morrison, A. M. (2018). Marketing and managing tourism destinations. Routledge.

Novalius. (2019). Penjualan Semen Baturaja Meroket 24\% Sepanjang 2018: Okezone Economy.

Odin, Y., Odin, N., \& Valette-Florence, P. (2001). Conceptual and operational aspects of brand loyalty: An empirical investigation. Journal of business research, 53(2), 75-84. https://doi.org/10.1016/S0148-2963(99)00076-4

Putra, I. W. G. G. P., \& Sulistyawati, E. Peran Brand Trust Memediasi Pengaruh Brand Image Terhadap Brand Loyalty. E-Jurnal Manajemen, 8(7), 4328-4356.

Qurbani, D., \& Pasaribu, V. L. D. (2019). Pengaruh Brand Image Dan Brand Trust Terhadap Brand Loyalty Nasabah Prudential Syariah Pada PT. Futuristik Artha Gemilang (Studi kasus di kantor cabang agensi Prudential Syariah PT. Futuristik Artha Gemilang Jakarta Selatan). Jurnal Pemasaran Kompetitif, 2(3), 121-135.

Rossiter, J. R., \& Bellman, S. (2005). Marketing communications. Pearson/Prentice Hall.

Rusmiati, N. N., Sugiati, I. G. A., Purnami, A. S., \& Amerta, I. M. S. (2020). The effect of brand image and country of origin on consumer buying interest: case study on Yamaha NMAX motorcycle in Denpasar city. International Research Journal of Management, IT and Social Sciences, 7(3), 83-90. 
Setiadi, N. J. (2003). Perilaku konsumen: Konsep dan implikasi untuk strategi dan penelitian pemasaran. Jakarta: Prenada Media, 125.

Setyawan, A., Arini, F. Y., \& Akhlis, I. (2017). Comparative Analysis of Simple Additive Weighting Method and Weighted Product Method to New Employee Recruitment Decision Support System (DSS) at PT. Warta Media Nusantara. Scientific Journal of Informatics, 4(1), 34-42.

Sidjabat, F. M., Habibah, R., \& Pasaribu, M. (2019). Comparative Analysis of Quality and Environmental Management Strategic Implementation in Cement Industry. Media Ilmiah Teknik Lingkungan (MITL), 4(2), 58-70.

Wahyuni, D. (2012). The research design maze: Understanding paradigms, cases, methods and methodologies. Journal of applied management accounting research, 10(1), 69-80.

Zehir, C., Şahin, A., Kitapçı, H., \& Özşahin, M. (2011). The effects of brand communication and service quality in building brand loyalty through brand trust; the empirical research on global brands. Procedia-Social and Behavioral Sciences, 24, 1218-1231. https://doi.org/10.1016/j.sbspro.2011.09.142

Santri, B., Wahab, Z., Widiyanti, M., \& Shihab, M. S. (2021). Effect of image and brand trust on loyalty of cement baturaja consumers. International Research Journal of Management, IT and Social Sciences, 8(2), 141-147. https://doi.org/10.21744/irjmis.v8n2.1300 